\title{
Distinctive Contours of Jesuit Enlightenment in France
}

\author{
Jeffrey D. Burson
}

Due largely to their persecution of more radical strains of Enlightenment that emerged from Diderot's editorship of the Encyclopédie, many historians have too commonly neglected the important contributions of French Jesuit scholars to eighteenth-century culture. The distinctiveness of French Jesuit contributions to scholarship during the century of Enlightenment is the subject of this chapter. This chapter also emphasizes some of the ways in which the radicalization of the eighteenth-century French siècle de lumières-specifically its strains of atheism and materialism - were ironically shaped, however accidentally and indeed unintentionally, by debates already well underway among Jesuit intellectuals themselves. ${ }^{1}$ Accordingly, this chapter participates in a broader trend, evident among church historians as well as intellectual historians, of restoring agency to Jesuit writers in helping to forge the scholarly milieu from which emerged the wider European Enlightenment, even if the Jesuit contribution to the Enlightenment is often ironic in that many philosophes subverted the original impetus for Jesuit scholarship. This chapter also participates in scholarly conversations sparked in various ways by historians Alan C. Kors, Ann Thomson, and Margaret C. Jacob whose work situates the origins of Enlightenment radicalism in France, not strictly within a supposedly Spinozan atheism but rather within a more complex dialogue among theologians, scientists, and lay writers throughout Western Europe. ${ }^{2}$

1 The standard work on the Jesuit contributions to the Enlightenment remains Robert R. Palmer, Catholics and Unbelievers in Eighteenth-Century France (Princeton, NJ: Princeton University Press, 1939); Dale K. Van Kley, "Robert R. Palmer's Catholics and Unbelievers in Eighteenth-Century France: An Overdue Tribute," Historical Reflections/Réflexions Historiques 37, no. 3 (Winter 2011): 18-37. My own research nuances and contextualizes Palmer by noting how the Jesuit engagement with the Enlightenment ebbed and flowed in ways that both reacted to, and inadvertently created, the radicalization of the Enlightenment.

2 Alan C. Kors, Atheism in France, 1650-1729, vol. 1: The Orthodox Sources of Disbelief (Princeton, NJ: Princeton University Press, 1990); Ann Thomson, Bodies of Thought: Science, Religion, and the Soul in the Early Enlightenment (Oxford: Oxford University Press, 2008; repr. 2010), 22-27, 229-37; Thomson, L'âme des lumières: Le débat sur l'être humain

(C) JEFFREY D. BURSON, 2016 | DOI 10.1163/9789004313354_013

This is an open access chapter distributed under the terms of the Creative Commons Attribution- 
Any chapter on Jesuit contributions to the eighteenth century necessarily entails some discussion of the relationship between Jesuit erudition and the Enlightenment. The question is not without its many complexities, if only because there is presently no clear consensus among eighteenth-century scholars as to how the Enlightenment ought to be defined, or when and where it took place. Conventionally, the Enlightenment has been defined as a largely (but not exclusively) eighteenth-century cultural and intellectual movement that optimistically assumed that extensive improvement of human nature was possible through educational reform, the popularization of the scientific method of empirical reason and its pervasive application to practical problems of sociopolitical reform. In addition, the Enlightenment is often defined as being almost essentially motivated by "modern paganism" whether in the form of attacks on established clergies, religious orthodoxies and orthopraxis, or a pervasive materialism that favored the disenchantment of nature and the secularization of the concept of the mind and soul. ${ }^{3}$ Complicating these rather straightforward

entre religion et science Angleterre-France (1690-1760) (Paris: Epoques Champ Vallon, 2013); Thomson, “'Mechanistic Materialism' vs. 'Vitalistic Materialism'?" in La Lettre de la Maison française d'Oxford 14 (2001): 22-36; also John Wright, "Materialismo e anima vitale alla metà del XVIII secolo. Il pensiero medico," in L'Età dei Lumi: Saggi sulla cultura settecentesca, ed. Antonio Santucci (Bologna: Società editrice il Mulino, 1998), 143-57; Margaret C. Jacob, Living the Enlightenment: Freemasonry and Politics in EighteenthCentury Europe (New York: Oxford University Press, 1991); cf. Jonathan I. Israel, A Revolution of the Mind: Radical Enlightenment and the Intellectual Origins of Modern Democracy (Princeton, NJ: Princeton University Press, 2010), 1-36; Israel, Democratic Enlightenment: Philosophy, Revolution, and Human Rights, 1750-179o (Oxford: Oxford University Press, 2011), 1-36; Israel, Revolutionary Ideas: An Intellectual History of the French Revolution from the Rights of Man to Robespierre (Princeton, NJ: Princeton University Press, 2014); Israel, Radical Enlightenment: Philosophy and the Making of Modernity, 1650-1750 (Oxford: Oxford University Press, 2001); and Israel, Enlightenment Contested: Philosophy, Modernity, and the Emancipation of Man, 1670-1752 (Oxford: Oxford University Press, 2006), $3^{-60 .}$

3 Peter Gay, The Enlightenment: An Interpretation-The Rise of Modern Paganism (New York: Alfred A. Knopf, 1967); Ira O. Wade, The Structure and the Form of the French Enlightenment, 2 vols. (Princeton, NJ: Princeton University Press, 1987); also more recently, Anthony Pagden, The Enlightenment and Why It Still Matters (New York: Random House, 2013); also Georges Gusdorf, Les principes de la pensée au siècle des lumières (Paris: Payot, 1971); Ernst Cassirer, The Philosophy of the Enlightenment, trans. Fritz C.A. Koellen and James P. Pettegrove (Princeton, NJ: Princeton University Press, 1951); Stephen Bronner, Reclaiming the Enlightenment: Toward a Politics of Radical Engagement (New York: Columbia University Press, 2004); for alternative, and far more critical adherents of the unitary Enlightenment 
descriptions are the various ways in which scholars emphasize or deemphasize certain specific aspects of the Enlightenment, and in this way, reframe its historical significance. Ever since the historian J.G.A. Pocock (1924-) first raised the issue in the context of the English Enlightenment, some scholars have favored the subdivision of the Enlightenment project into various Enlightenments, many of which could not be described as uniformly anticlerical. ${ }^{4}$ Thus it is now possible to speak of various styles of "Religious Enlightenment" - a "Jewish Enlightenment," a "Protestant Enlightenment," and a "Catholic Enlightenment" - or even different variants within the Catholic Enlightenment. ${ }^{5}$ Still others, beginning with the authors of the seminal volume, The Enlightenment in National Context, historians Roy Porter (1946-2002) and Mikuláš Teich, have preferred to

thesis, see Jean-François Lyotard, The Postmodern Condition: A Report on Knowledge, trans. Geoff Bennington and Brian Massumi (Minneapolis: University of Minnesota Press, 1984), xxiii-xxiv, 29-31; Michel Foucault, “What is Enlightenment?” in The Foucault Reader, ed. Paul Rabinow (New York: Pantheon Books, 1984), 32-51; Max Horkheimer and Theodor Adorno, The Dialectic of Enlightenment: Philosophical Fragments, ed. Gunzelin Schmid Noerr, trans. Edmund Jephcott (Stanford: Stanford University Press, 2012); on Enlightenment connections to Western chauvinism and the construction of "orientalism" to justify imperialism, see Edward Said, Orientalism (New York: Basic Books, 1979).

4 J.G.A. Pocock, Barbarism and Religion: The Enlightenments of Edward Gibbon, 1737-1764 (Cambridge: Cambridge University Press, 1999), 1:9.

5 David Sorkin, The Religious Enlightenment: Protestants, Jews, and Catholics from London to Vienna (Princeton, NJ: Princeton University Press, 2008); Hugh Trevor-Roper, De la Réforme aux Lumières, trans. Laurence Ratier (Paris: Éditions Gallimard, 1974); Ulrich Lehner, "What is Catholic Enlightenment?" in Companion to the Catholic Enlightenment in Europe, ed. Ulrich L. Lehner and Michael Printy (Leiden: Brill, 2010), 1-62; Shmuel Feiner, The Jewish Enlightenment, trans. Chaya Naor (Philadelphia: University of Pennsylvania Press, 2004); Dale K. Van Kley, "Plots and Rumors of Plots: The Role of Conspiracy in the International

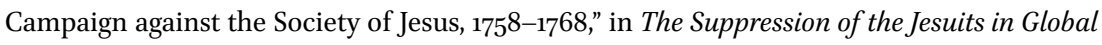
Context: Causes, Events, and Consequences, ed. Jeffrey D. Burson and Jonathan Wright (Cambridge: Cambridge University Press, 2015), 15-49; Van Kley, "From the Catholic Enlightenment to the Risorgimento: The Debate between Nicola Spedalieri and Pietro Tamburini, 1791-1797," Past and Present 224, no. 1 (2014): 109-62; Van Kley, "Robert R. Palmer's Catholics and Unbelievers in Eighteenth-Century France: An Overdue Tribute," in Sacred and Secular Agency in Early Modern France: Fragments of Religion, ed. Sanja Perovic (London: Bloomsbury, 2012), 13-37; Jeffrey D. Burson, "The Catholic Enlightenment in France from fin de siècle Crisis to Revolution, c.1650-1789," in Lehner and Printy, Companion to the Catholic Enlightenment, 23-125. I have since modified my views somewhat, and no longer fully ascribe to distinct "Augustinian" versus "pro-Bull" styles of Catholic Enlightenment. For an updated interpretation, see most recently in Burson, "Introduction: Catholicism and Enlightenment, Past, Present, and Future," in Enlightenment and Catholicism in Europe, 1-39. 
divide the various "enlightenments" along national or state boundaries. ${ }^{6}$ More controversial, but still very intriguing, has been the tendency to point up the ways in which Counter-Enlightenment writers such as Joseph de Maîstre (17531821) in factimmersed themselves in the critical scholarship of the Enlightenment in order to refute it. ${ }^{7}$ At the very least, this focus has forced eighteenth-century specialists to rethink the Counter-Enlightenment and reframe it as more precisely being against radical philosophes and not perhaps the Enlightenment as a whole. ${ }^{8}$ Such complexity has prompted a kind of reaction in favor of seeing the Enlightenment as being primarily concerned with practical economic and political reforms-particularly a desire to improve existing dynastic states through application of modern political economy, abolition or amelioration of serfdom and feudalism, improvement of education, and allowing a reformed state to clean up the abuses wrought by religious establishments. ${ }^{9}$ With these emphases has come fascinating and innovative work on various forms of Enlightened Absolutism throughout Europe. ${ }^{10}$ Jonathan Israel (1946-) of the Princeton Institute of Advanced Studies, on the other hand, has preferred to see rationalism, materialism, atheism, and egalitarianism as the essential force for modernization for which, in his judgment, the Enlightenment is responsible. Israel's volumes controversially trace what he considers the Enlightenment vanguard - the Radical Enlightenment, especially of Spinoza (1632-77) — throughout nearly two centuries from 1650 in the Netherlands and onward. ${ }^{11}$ Still others

$6 \quad$ Roy Porter and Mikuláš Teich, eds., The Enlightenment in National Context (Cambridge: Cambridge University Press, 1981).

7 Carolina Armenteros, "Introduction," Joseph de Maistre and the Legacy of Enlightenment, ed. Carolina Armenteros and Richard A. Lebrun (Oxford: Voltaire Foundation, 2011), 4, 5.

8 Darrin McMahon, Enemies of Enlightenment: The French Counter-Enlightenment and the Making of Modernity (Oxford: Oxford University Press, 2001); Didier Masseau, Les ennemis des philosophes: L'antiphilosophie au temps des Lumières (Paris: Albin Michel, 2000).

9 John Robertson, The Case for the Enlightenment: Scotland and Naples, 1680-1750 (Cambridge: Cambridge University Press, 2005).

10 Jeremy Adelman, Sovereignty and Revolution and the Iberian Atlantic (Princeton: Princeton University Press, 2006); Gabrielle Paquette, Enlightenment, Governance, and Reform in Spain and Its Empire, 1759-1808 (Basingstoke: Palgrave Macmillan, 2008); John Shovlin, The Political Economy of Virtue: Luxury, Patriotism, and the Origins of the French Revolution (Ithaca: Cornell University Press, 2006); also Charles C. Noel, "Clerics and Crown in Bourbon Spain, 1700-1800: Jesuits, Jansenists, and Enlightened Reformers," in Religion and Politics in Enlightenment Europe, ed. James E. Bradley and Dale K. Van Kley (Notre Dame: Notre Dame University Press, 2001), 119-53.

11 Israel, Radical Enlightenment; Israel, Enlightenment Contested; most recently, Israel, Democratic Enlightenment, $55^{8-72}$, and the parallel and dubious extrapolations from his 
have emphasized quite the contrary - the distinctively irrational or even premodern faces of the so-called century of Enlightenment and its continuities with humanism and late early modern Hermeticism. Indeed, classical republican thought, indebted as much to the fourteenth through seventeenth centuries as to the eighteenth, has also been given a privileged position in the transformation of eighteenth-century political and revolutionary thought. ${ }^{12}$

It is far beyond the scope of this essay on the Jesuits to delve more thoroughly into every niche of so many historiographical controversies; I mention them here only as an important caveat to what follows, namely that with almost no agreement concerning what the Enlightenment is, it is very hard to address whether, or to what extent, one might speak of a Jesuit contribution to the Enlightenment. In any event, I have addressed the thornier issue of whether there truly was a Jesuit Enlightenment elsewhere. ${ }^{13}$ Rather, this essay will solely describe some salient characteristics of Jesuit scholarship in order to elucidate the distinctiveness of the Jesuit contribution to the eighteenth century. If one defines the Enlightenment as being essentially about the limitless ability of human reason to improve itself by criticizing all forms of authority, especially established religious authorities, and if the disenchantment of nature to the point of materialism or even atheism is similarly vital to the Enlightenment, then it must be said that the Jesuit contribution to the century of the Enlightenment was vastly different.

Many Jesuits in Europe, including and especially French Jesuits associated with their Parisian school Louis-le-Grand, were among the cultural elite of the early to middle eighteenth-century republic of letters. Many believed that advancements in natural philosophy, history, epistemology, and science could and should be used, both for the moral edification of society, and for the apologetic utility of their own promotion and defense of the Catholic faith. The Jesuit René-Joseph

earlier arguments on the Radical Enlightenment origins of the French Revolution in Israel, Revolutionary Ideas.

12 David Allen Harvey, Beyond Enlightenment: Occultism and Politics in Modern France (DeKalb, IL: Northern Illinois University Press, 2005); Dan Edelstein, The Super Enlightenment: Daring to Know Too Much (Oxford: Voltaire Foundation, 2005); Marisa Linton, The Politics of Virtue in Enlightenment France (Basingstoke: Palgrave Macmillan, 2001); Dale K. Van Kley, "Civic Humanism in Clerical Garb: Gallican Memories of the Early Church and the Project of Primitivist Reform, 1719-1791," Past and Present 1 (2008): 77-120; Van Kley, "Religion and the Age of 'Patriot' Reform," Journal of Modern History 80 (2008): 252-95.

13 Jeffrey D. Burson, "Between Power and Enlightenment: Cultural and Intellectual Context of the Jesuit Suppression in France," in The Jesuit Suppression: Causes, Events, Consequences, ed. Jeffrey D. Burson and Jonathan Wright (Cambridge: Cambridge University Press, 2015), 50-81. 
Tournemine (1661-1739) affords us an important example of this approach. In citing the example of the Jesuit missionaries of China, Tournemine noted that not until Matteo Ricci (1552-1610) did Christianity achieve success in China, and the ticket to such success lay in the Jesuits' ability to address the interests of the Chinese scholar gentry in mathematics and natural philosophy. In Tournemine's judgment, therefore, the grace of God was necessary and efficacious for conversion, but divine grace, he argued, often worked through human agency, and thus has more chance of achieving its end if missionary-scholars like the Jesuits affect to be "all things to all people."14 Progress in the arts and letters, and in particular in mathematics and modern science, was considered by many eighteenth-century Jesuits as the means by which grace must come to a new, more enlightened generation. And this fact, Tournemine believed, would be true as much of Europe as it was in China. ${ }^{15}$

Early in the eighteenth century, Tournemine was among an influential cadre of Jesuits who articulated a broadening of the Jesuit spirit of the Ratio studiorum for the eighteenth-century age of Enlightenment: he exhorted that one must approach study, sometimes even of suspect authors and non-Christian texts, as a prayerful act and a means of devoting one's heart and will to God, because in so doing, the church would better address the concerns of the cosmopolitan eighteenth century. ${ }^{16}$ Engagement with an increasingly globalized corpus of texts from human antiquity (even outside of Europe) and critical engagement with the textual output of the Enlightenment was to serve an apologetical and ultimately evangelical end: the defense and dissemination of what Jesuits considered to be the one truly divine religion.

For this reason, surmised Tournemine, the elites of the early eighteenth century continued to flock to the Jesuits, just as Chinese elites had flocked to seventeenth-century Jesuit missionaries, because the Jesuit order was able to teach the sciences and arts most useful to the sons of the nobles and haute bourgeoisie, while preserving and fortifying their commitment to the church. Unlike the early days of Christianity, Tournemine warned, "the time of having any hope of rendering very much glory to God, or very much service to one's neighbor without the support of divine and human sciences is no more."17

14 Florence C. Hsia, Sojourners in a Strange Land:Jesuits and Their Scientific Missions in Late Imperial China (Chicago: University of Chicago Press, 2009), 1.

15 "C'est toujours la grace qui convertît, mais la grace a plus d'une manière d'arriver ses fins et c'est en se faisant tous à tous, qu'on trouve enfin à quoy c'est qu'elle a attaché le salut de tous." [Tournemine], "Discours sur les Etudes de la Compagnie," BnF, Nouvelles acquisitions françaises 10946, 366 .

16 Ibid., 367-68.

17 "Le temps n'est plus n'est où sans secours des Sciences divines et humaines nous puissions espérer de rendre ni à dieux beaucoup de gloire ni beaucoup de service au Prochain." 
As was hitherto the case since the Society's inception, the Jesuits thought that their belletristic and philosophical curricula were an intrinsic part of their evangelism and apologetics, but with the eighteenth century came a renewed emphasis on the manner in which Jesuit erudition advanced their divine mission by also promoting social utility and the moral improvement of humanity. In what follows, I will develop this overarching emphasis by more closely examining the intersection of Jesuit moral philosophy, apologetics, and historicism; it is in no way intended to be a comprehensive study of the totality of Jesuit scholarship in the eighteenth century. ${ }^{18}$

\section{Eighteenth-Century Jesuit Moral Philosophy, Apologetics, and Historicism}

Insofar as a general optimism concerning the predilection of human nature for rational reform and improvement is crucial to the spirit of the century, there remains no question that many Jesuits shared such optimism whether or not

Ibid., 332; also 331, 345; see also Martin A. Lynn, The Jesuit Mind: The Mentality of an Elite in Early Modern France (Ithaca: Cornell University Press, 1988), 231.

18 Insofar as Jesuit epistemology and Jesuit natural science has received extensive study elsewhere, the current chapter will not revisit these topics extensively. For Jesuit epistemological innovation, see Jeffrey D. Burson, The Rise and Fall of Theological Enlightenment: Jean-Martin de Prades and Ideological Polarization in Eighteenth-Century France (Notre Dame, IN: University of Notre Dame Press, 2010); Burson, "Claude G. Buffier and the Maturation of the Jesuit Synthesis in the Age of Enlightenment," Intellectual History Review 21, no. 4 (December 2011): 449-72; Catherine M. Northeast, The Parisian Jesuits and the Enlightenment, 1700-1762 (Oxford: Voltaire Foundation, 1991); Buffier's "Remarques sur la métaphysique de M. Locke" was published alongside the 1725 edition of his Traité des premières vérités: see Bouillier, "Introduction," Oeuvres philosophiques du Père Buffier (Paris: Adolphe de la Haye, 1843), 131; Ross Hutchison, Locke in France, 1688-1734 (Oxford: Voltaire Foundation, 1991), 35-39; for the most helpful and foundational treatments, see François de Dainville, L'éducation des jésuites, XVI-XVIIIe siècles (Paris: Éditions de Minuit, 1978); Mordechai Feingold, ed., Jesuit Science and the Republic of Letters (Cambridge, MA: MIт Press, 2002); Marcus Hellyer, Catholic Physics:Jesuit Natural Philosophy in Early Modern Germany (Notre Dame, In: University of Notre Dame Press, 2005); John W. O'Malley et al., eds., The Jesuits: Cultures, Sciences, and the Arts, 1540-1773 (Toronto: University of Toronto Press, 1999); John W. O'Malley et al., eds., The Jesuits II: Cultures, Science, and the Arts, 15401773 (Toronto: University of Toronto Press, 2002); also portions of J.B. Shank, The Newton Wars and the Beginning of the French Enlightenment (Chicago: University of Chicago Press, 1995); Christian Albertan, "Entre foi et sciences: Les Mémoires de Trévoux et le mouvement scientifique dans les années 50," Dix-huitième siècle 34 (2002): 91-97. 
one views Jesuit contributions to the eighteenth as a vital part of the Enlightenment or not. ${ }^{19}$ This optimism included the willingness to entertain the existence of a historical state of pure nature before the fall that lasted, despite gradual decline, for some time even afterward. Such speculations concerning the slow end of this more optimistic state of nature provided a theological justification for the integrity of their moral theology and sometimes even facilitated debate with early Enlightenment writers. But contrary to the frequent accusations by Jansenists that Jesuits followed Luis de Molina (1535-160o), most Jesuits actually invoked their understanding of the authority of Thomas Aquinas (1225-74) to defend their notions about human nature, notions which unsurprisingly remained rooted in the Council of Trent: that Adam was created with a human nature that was essentially pure and perfectible. ${ }^{20}$ Indeed, this must be the case since a perfect God could not have created an essentially defective human nature. Accordingly, Jesuits understood supernatural grace to have fortified Adam's nature until the fall, at which point this efficacious grace was revoked and human nature slowly drifted into sin. The Jesuit view represented a critical departure from the prevailing opinion of many French clergy influenced by Pasquier Quesnel's (1634-1719) interpretation of the fall-that human nature had been corrupted at its essence. To Jesuits, Quesnel's interpretation, which many Jansenists shared (and even many non-Jansenist servants of the Gallican church), implied that the choice of the first man to sin could unmake an essence over which God alone possessed the power of creation. ${ }^{21}$ Jesuit moral philosophy thus presupposed a generally more optimistic appraisal of human nature which facilitated dialogue with the developing Enlightenment during the eighteenth century, and in fact, often comported well with the "rehabilitation of human nature" assumed by many less orthodox writers of the middle eighteenth century. ${ }^{22}$

Yet, because Jesuits believed by faith that human nature was not depraved at its essence, but instead that the perfective and supernatural grace of God was only removed at the fall, it therefore became possible to conceive of an early and even partially postlapsarian state of nature that had degenerated over time owing to the very nature of the human soul when no longer ignited

\footnotetext{
19 Palmer, Catholics and Unbelievers, 117-25.

2o Alexander Aichele and Matthias Kaufmann, eds., A Companion to Luis de Molina (Leiden: Brill, 2013).

21 Jean Ehrard, L'Idée de la nature en France dans la première moitié du XVIIIe siècle (Geneva: Slatkine, 1981; 1969), 438-40.

22 Northeast, Parisian Jesuits, 217-18; Roger Mercier, La réhabilitation de la nature humaine, 1700-1750 (Villemomble: Éditions La Balance, 1960).
} 
and perfected by supernatural grace. As Claude Buffier (1661-1737), the Jesuit editor of the Mémoires de Trévoux (Memoirs of Trévoux), argued, the natural sentiment of humanity-our common sense-was warped after the fall because natural reason was then inexorably dependent upon sense perception. ${ }^{23}$ This definition of original sin as resulting from the natural corruptibility of human understanding and moral behavior unites Jesuit moral philosophy with views shared by other Enlightenment thinkers. Pierre Bayle (1647-1706) argued that primitive humanity found itself beset by fear of inexplicable natural forces, and that this in turn led to superstition and idolatry. ${ }^{24}$ For John Locke (1632-1704), whose views were among those which directly informed Buffier's own, early humans, while still bereft of natural science, tended to ascribe inexplicable natural catastrophes to the vengeance of angry anthropomorphic beings inhabiting nature. These entities were thought to require appeasement, and were therefore worshiped as gods or spirits. Such was the opinion of Locke, for example, and it was in many respects apologetically adapted by Buffier in works such as Traité des premières vérités (Treatise concerning first principles) that effectively blended different strains of Cartesianism with Locke's sense-based empiricism. ${ }^{25}$ Enlightenment writers

23 Claude G. Buffier, Traité des premières vérités et de la source de nos jugements, in Oeuvres philosophiques de P. Buffier, introduced by Francisque Bouillier (Paris: Adolphe de la Haye, 1843), I.ix, 33-35, 72-76.

24 Frank E. Manuel, The Eighteenth Century Confronts the Gods (Cambridge, MA: Harvard University Press, 1959), 26-31; Paul Hazard, La crise de la conscience européene, 1680-1715 (Paris: Librairie Arthème Fayard, 1961), 90-109.

25 Buffier, Traité des premières vérités et de la source de nos jugements, I.i.9, 7; I.ii.17, 10; I.v.41, 45, 18-19; Kathleen Wilkins, A Study of the Works of Claude Buffier (Geneva: Institut et Musée de Voltaire Les Délices, 1969); Hutchison, Locke in France, 35-39; on the distinction among Cartesianisms, see Tad M. Schmaltz, Radical Cartesianism: The French Reception of Descartes (Cambridge: Cambridge University Press, 2002), 11; Schmaltz, "Descartes and Malebranche on Mind and Mind-Body Union," Philosophical Review 101, no. 2 (April 1992): 286-95; Thomas M. Lennon and Patricia Ann Easton, The Cartesian Empiricism of François Bayle (New York: Garland Publishing, 1992), 1-4; on the influence of Buffier, and his own roots in both Locke and Malebranche, see Burson, "Claude G. Buffier," 449-72; Burson, Rise and Fall of Theological Enlightenment, 1-274; for the use of Locke, Malebranche, and the place of "Cartesian empiricism" in Jesuit epistemology during the eighteenth century, see Jeffrey D. Burson, "Healing the Pyrrhonian Sickness and Rectifying Cartesianisms: The Notion of the Jesuit Synthesis Revisited," in Age of Skepticism:Doubt, Reason, Religion, and Politics in Eighteenth-Century Culture, ed. Jeffrey D. Burson and Anton Matytsin (Oxford: Oxford University Studies on Voltaire in the Enlightenment, forthcoming); Bernard Cottret, Le Christ des Lumières: Jésus de Newton à Voltaire, 1680-1760 (Paris: Éditions du Cerf, 1990), 57, 75-76; Manuel, Eighteenth Century Confronts the Gods, 44-55, 62-63, 132. 
and many Jesuits located the origins of superstition and idolatry in fear-driven failures of human understanding.

Because Jesuits accepted that human understanding (whether concerning moral, religious, or scientific "facts") was liable to corruption because of the very nature of sense perception, all of them concluded that natural theology would never be sufficient, and in this respect, they differed from more radical writers in the later years of the Enlightenment, for whom reason was sufficient. Jesuits contended that individual reason, even once properly enlightened, remained powerless to maintain or rediscover the pristine natural revelation of God. Thus, Jesuits and other apologists of the eighteenth century only considered the revealed religion of the Catholic Church to be philosophically necessary as an effective bulwark against the inherently corruptive tendencies of natural reason. However, for such a claim to be palatable to eighteenth-century readers, the Jesuits became the vanguard of a style of apologetics that attempted to demonstrate that the traditions of the church and its teachings were historically verifiable in toto in an unbroken succession dating to within living memory of Jesus himself. ${ }^{26}$ The task before many eighteenth-century apologists, then, was to develop methods based on empirical principles that would more aptly verify the likely divine inspiration of the Catholic religion based on historical evidence. These apologetics drew from an eclectic array of sources, and were designed to guide the reader to the conclusion that divine revelation rested with the church and was the only surety against the vulnerability of human understanding to fears, passions, and the needs of the body.

To a great extent, the eighteenth-century pedagogical ethos of the Jesuit scriptores concerning moral philosophy, apologetics, and natural science remained rooted in sixteenth- and seventeenth-century humanism. This reality begs an important question: what is so distinctive about the Jesuit contribution to the eighteenth century? In other words, what is really so different from early modern modes of Renaissance criticism and natural philosophy in which the Society participated from its founding? In answering this question, one does well to recall that this question has been asked of the Enlightenment more generally, and many scholars are revisiting the continuities between the sixteenth and eighteenth centuries as a whole. ${ }^{27}$ Ann Thomson's recent work

26 Burson, Rise and Fall of Theological Enlightenment, 64-70.

27 For my own reflections on narrowing the gap between sixteenth- and eighteenth-century intellectual history, see Jeffrey D. Burson, "Tracing the Genealogy of Revolt against 'Esprit de système' from the Renaissance to the Enlightenment," in Ideas, Aesthetics, and Inquiries in the Early Modern Era, 1650-1850, ed. Kevin Cope (New York: AMs Press, 2016). 
has underscored the importance of early seventeenth-century religious debates to the circulation of more radical scientific materialism in the eighteenth century. ${ }^{28}$ Dennis Des Chene and Anthony Kenny, historians of philosophy, have reminded us of the subtle but dynamic evolution of Aristotelian modes of Scholasticism and natural philosophy that to a large extent served as prelude to the Enlightenment. ${ }^{29}$ Historian Dan Edelstein's genealogy of the Enlightenment firmly roots at least the French Enlightenment in the quarrel over the primacy of the ancients and moderns on the one hand, and the enduring legacy of Greek and Roman writers on the other. ${ }^{30}$ Scholars such as Neven Leddy, Avi Lifschitz, Thomas Ahnert, Charles T. Wolfe, and James A. Harris have revisited the role of Epicurean texts and motifs to the Enlightenment, while intellectual historian Tim Stuart-Buttle has recently made the controversial but fascinating suggestion that Cicero was more commonly cited during the eighteenth century than the sixteenth. ${ }^{31}$ To consider the culture of the eighteenth century, including that of the Enlightenment, as firmly rooted in gradual changes to various modes of early modern scholarship dating to the Renaissance at least is not uncommon today, and such continuities afford us more space to examine Jesuit contributions to the Enlightenment, not less.

To observe, quantify, and apprehend nature was an act of moral edification, and in that sense, directly descended from the gentlemanly ideal of the vir virtutis. Study of nature supplemented and corrected study of ancients for the moral utility of society. While arguably unique among Catholic Reformation religious orders, this Jesuit intersection of piety and pedagogy is the same as the self-fashioned identity of the scholar-missionary so central to the scientific missionaries studied by cultural historian Florence Hsia, and it is related to the same polymathic ideal that motivated Leibniz $(1646-1716)$ and Descartes

28 Thomson, Bodies of Thought, 22-27, 229-37; Thomson, L'âme des Lumières.

29 Dennis Des Chene, Physiologia: Natural Philosophy in Late Aristotelian and Cartesian Thought (Ithaca: Cornell University Press, 1996), 3-4; Anthony Kenny, Essays on the Aristotelian Tradition (Oxford: Clarendon Press, 2001), 5-6, 9.

30 Dan Edelstein, The Enlightenment: A Genealogy (Chicago: University of Chicago Press, 2010), 1-19, 37-52.

31 Thomas Ahnert, "Epicureanism and the Transformation of Natural Law in the Early German Enlightenment"; Charles T. Wolfe, "A Happiness Fit for Organic Bodies: La Mettrie's Medical Epicureanism"; James A. Harris, "The Epicurean in Hume"; Neven Leddy, "Adam Smith's Critique of Enlightenment Epicureanism"; Avi S. Lifschitz, "The Enlightenment Revival of the Epicurean History of Language and Civilisation," in Epicurus in the Enlightenment, ed. Neven Leddy and Avi S. Lifschitz (Oxford: Voltaire Foundation, 2009), 53-69, 69-85, 161-83, 183-207, 207-27; also Tim Stuart-Buttle, Cicero and the Science of Man in Britain from Locke to Hume, c.166o-c.176o (Oxford: Oxford University Studies in the Enlightenment, in progress). 
(1596-1650). What is increasingly distinctive about the Jesuit scholarship of the eighteenth century, however, is its emphasis on the intersection of Catholic erudition, apologetics, and social utility. ${ }^{32}$ The use of empirical reason to sound out its own limits, probe the depths of natural wonders, and discern commonalities and discontinuities within an increasingly global corpus of ancient texts (often translated and studied by Jesuit missionary-scholars themselves) was considered even more vital to the reform of society and promotion of Catholic piety in the eighteenth century. Such a subtle but significant shift toward historical-critical apologetics, and the augmentation of their socio-religious importance, is already evident in the early years of the eighteenth century. Jesuits thus made distinctive contributions to such historical apologetics, and even derived important methods of historical historicity to evaluate historical sources and eyewitness testimony. Buffier in particular derived important methods of historical historicity to evaluate historical sources and eyewitness testimony. Buffier did so by expanding upon Locke's rules for historical probability, and he used them to develop methods for evaluating the historical certitude of the Gospels and the authenticity of the Catholic Church's revealed teachings. ${ }^{33}$ Such methods became widely

32 On the cultural continuities between the emergence of the seventeenth-century revolution in natural philosophy and the culture of the Renaissance, see Matthew L. Jones, The Good Life in Scientific Revolution: Descartes, Pascal, Leibniz, and the Cultivation of Virtue (Chicago: University of Chicago Press, 2006); Paula Findlen, Possessing Nature: Museums, Collecting, and Scientific Culture in Early Modern Italy (Berkeley: University of California Press, 1994), 365-66, 376-80; for additional sources (beyond those cited previously) concerning the globalization of the European consciousness as a result of Jesuit missionary activities and the translation of non-European texts into European cultural consciousness, see Vicente L. Rafael, Contracting Colonialism:Translation and Christian Conversation in Tagalog Society under Early Spanish Rule (Durham, NC: Duke University Press, 1993, 1998); Walter D. Mignolo, The Darker Side of the Renaissance: Literacy, Territoriality, and Colonization, 2nd ed. (Ann Arbor: University of Michigan Press, 1995; 2003); Guy Stroumsa, A New Science: The Discovery of Religion in the Age of Reason (Cambridge, MA: Harvard University Press, 2010), 5-13; Harry Liebersohn, The Traveler's World: Europe to the Pacific (Cambridge, MA: Harvard University Press, 2006), 1-14, 299-305.

33 For Buffier, see Katharine J. Hammerton, "A Feminist Voice in the Enlightenment Salon: Madame de Lambert on Taste, Sensibility, and the Feminine Mind," Modern Intellectual History 7, no. 2 (2010): 216-20; Hammerton, "Malebranche, Taste, and Sensibility: The Origins of Sensitive Taste and a Reconsideration of Cartesianism's Feminist Potential," Journal of the History of Ideas 69, no. 4 (October 2008): 533-58; Burson, "Claude G. Buffier," 449-72; Burson, Rise and Fall of Theological Enlightenment, 1-274; Wilkins, Study of the Works of Claude Buffier; Ehrard, L'idée de la nature en France dans la première moitié du XVIII siècle, 424-25; Sophia Rosenfeld, "Before Democracy: The Production and Uses of 
popular and re-emerged almost wholesale even in the article on historical certitude in the Encyclopédie. ${ }^{34}$

In moving apologetics away from speculative reason and on to more historicalempiricist grounds, Buffier's efforts were in good company with earlier seventeenth-century works. Even from as early as the work by Jesuit controversialist François Véron (1575-1649), entitled Méthodes de traiter des controverses de religion (Methods for treating religious controversies) in 1638 , some Jesuits had attempted to disassociate speculative reason from the content of sacred mysteries themselves, making theology dependent more upon the moral proofs of historico-empirical analysis and textual transmission. As another Jesuit, PierreDaniel Huet (1630-1721), argued in his posthumously published critique of Descartes and Spinoza, Alnetanae quaestiones de concordia rationis et fidei (Questions concerning the concord of religion and faith, 169o), the veracity of dogma-even the veracity of such foundational doctrines as the existence of God and the immortality of the human soul-remains impervious to proofs afforded by speculative reason. ${ }^{35}$ Theology thereby became a science increasingly concerned with uncovering empirical evidence for the veracity of scriptural texts and church traditions in history — a point not far from Richard Simon's (1638-1712) own approach to biblical scholarship. In fact, despite his many critics, some Jesuit controversialists greatly admired Simon. The Jesuit Étienne Souciet (1671-1744) sent Simon manuscripts for critique, and the controversial Jesuit writer Jean Hardouin (1646-1729) was a friend of Simon as well. ${ }^{36}$

Common Sense," Journal of Modern History 80 (2008): 1-54; Francisque Bouillier, Histoire de la philosophie cartésienne, 3rd ed. (Paris: Charles Delagrave et Compagnie, 1868), 1:58889; Sebastien Charles, "L'immatérialisme allié naturel ou ennemi désigné des philosophes chrétiens?" Dix-huitième siècle 34 (2002): 161-72; Anton Matytsin, "The Specter of Skepticism and the Sources of Certainty in the Eighteenth Century, 1697-1772" (PhD diss., University of Pennsylvania, 2013), 154-210.

34 Buffier, Traité des premières vérités et de la source de nos jugements, I.xix,142-48, 62-65; I xxviii.175-79, 73-75; Essay concerning Human Understanding, ed. Peter H. Nidditch (Oxford: Clarendon Press, 1975), IV.xv.1-6, 654-57; IV.xvi.10-11, 663-5; IV.xviii.4, 690-91; Ehrard, L'Idée de la nature, 425-27; Burson, Rise and Fall of Theological Enlightenment, 64-70, 207-13; Hutchison, Locke in France, 35-39; Palmer, "The French Jesuits in the Age of Enlightenment," American Historical Review 45, no. 1 (October 1939): 44-58; Northeast, Parisian Jesuits, 65 .

35 Pierre-Daniel Huet, Alnetanae quaestiones de concordia rationis et fidei (Paris: Thomas Moette, Bibliopolam, prope Pontem S. Michaëlis, ad insigne S. Alexii, 169o), 4-5, 61, 74-75, http://catalog.hathitrust.org/Record/010390457; see the insightful discussion of Huet's Alnetanae in Matytsin, "Specter of Skepticism," 154-210.

36 Northeast, Parisian Jesuits, 56-63, 106-7; Daniel Watkins, "Enlightenment, Catholicism, Conservatism: The Isaac-Joseph Berruyer Affair and the Culture of Orthodoxy in France, 
The distinctiveness of eighteenth-century Jesuit historico-empirical apologetics similarly implied a renewed emphasis on finding concrete demonstrations of the process by which the original, natural religion/revelation from God (often identified with the religion of the biblical patriarchs) had been corrupted among the peoples of the globe. ${ }^{37}$ Jesuits thereby proved to be exceptionally important as participants in what Guy Stroumsa (1948-) has recently dubbed the "new science" of comparative religion during the Enlightenment. ${ }^{38}$ One of the most influential examples of this style of Jesuit apologetics was composed by the bishop of Avranches, Pierre-Daniel Huet (1630-1721), Buffier's predecessor as professor of philosophy at Louis-le-Grand, fellow scriptor, and later author of the Alnetanae. Huet's Demonstratio evangelica (1679) responded to Spinoza's critique of the historical authenticity of the Pentateuch with acclamation by the famous German philosopher of natural law, Samuel von Pufendorf (1632-94). In it, Huet argued that all peoples possessed corrupted copies of the Old Testament religion of the patriarchs preserved by Moses, and transmitted ultimately by Catholic Church teaching. Huet sustained his argument in a remarkable piece of erudition destined to become an eighteenthcentury progenitor of comparative religious history; its thesis, that the Pentateuch contained the most authentic surviving traits of God's original natural theology, cross-references ancient Greek and Roman sources with mythological, philosophical, and archeological sources from Egyptian, Chinese, Persian, Germanic, American Indian, and Celtic history. ${ }^{39}$ Huet's Demonstratio evangelica continued to be read in Jesuit and Lazarist seminaries throughout Paris as late as the $1740 \mathrm{os}$ and $175 \mathrm{os}$, and it served as a source of controversy and inspiration to many highly influential apologists of the $17205-50$ s, including Abbé d'Houtteville (1686-1742), author of Religion chrétienne prouvée par les faits (The Christian religion proven by facts; originally 1722 , but substantially

c.1700-1830" (PhD diss., Ohio State University, 2014), and Anthony Grafton, "Jean Hardouin: The Antiquary as Pariah," Journal of the Warburg and Courtauld Institutes 61 (1999): 241-67.

For varieties of apologetics during the Enlightenment and diverse interpretations of the Jesuit apologists, see Masseau, Les ennemis des philosophes; William R. Everdell, Christian Apologetics in France, 1730-1790: The Roots of Romantic Religion (Lewiston, NY: Edwin Mellen, 1987).

38 Stroumsa, New Science, 1-13, 145-57.

39 Huet, Demonstratio evangelica, Proposition III.i-xxi, cap. 1, 45-70; Proposition IV.i-xlii, cap. 2, 85-117; Proposition IV.i-vi, cap. 3, 117-22; Proposition IV.i-xi, cap. 4, 122-49; Proposition IV.i-ii, cap. 5, 149-6o; Proposition IV.i-iv, cap. 6, 161-67; Proposition IV.i-vi, cap. $7,167-76$. 
revised and reprinted in 1744), and Rodolphe du Tertre (1677-1762), author of Entretiens sur la religion (Dialogue concerning religion, 1743).40

In addition to historical apologetics—indeed they were building blocks for them-Jesuits also produced a veritable cascade of descriptive texts, philosophical abridgements, translations, and descriptions concerning numerous cultures throughout the world. Essential to this output, and the object of much study in recent years, is the tremendous textual output of the Jesuit missionaries to China. One of the French Jesuit missionaries, Philippe Couplet (1623-93), helped introduce the philosophy of Confucius to educated French audiences with Confucius Sinarum philosophus (Confucius, the philosopher of the Chinese, 1687). As a result, the European republic of letters swelled with debates about Chinese religion and moral philosophy, in addition to debates over the apparently well-ordered nature of Chinese politics. Chinese society appeared to mimic the ideal of Enlightened Absolutism that scholars (Jesuits and early philosophes alike) admired, and many Jesuits anchored the seeming exceptionalism of Chinese morality and government in the unprecedented length of time during which Jesuits believed that Chinese scholar gentry had maintained the purity of the so-called patriarchal revelation before its degeneration. Ricci's assertion that the Chinese had worshiped the Christian God, that Confucianism was therefore theistic and akin to Jesus's moral teachings, and that Confucianism had been corrupted only lately by Tang-Song materialists (618-1279) all proved foundational to this argument. ${ }^{41}$

40 Jean-Martin de Prades claimed inspiration from Huet during his years of association with the Lazarist Seminary of Bons-Enfants in Paris: see Jean-Martin de Prades, Apologie de Monsieur l'abbé de Prades, 2 vols. (Amsterdam: Marc-Michel Rey, 1752), 1:12; for additional details on Huet, see April G. Shelford, Transforming the Republic of Letters: Pierre-Daniel Huet and European Intellectual Life, 1650-1720 (Rochester, NY: University of Rochester Press, 2007); Northeast, Parisian Jesuits, 59-6o; Pufendorf, "Praefatio pro Petri Danielis Huetii [Pierre-Daniel Huet]," in Demonstratio evangelica ad Serenissimum Delphinum, $5^{\text {th }}$ ed. (Leipzig: Thomas Fritsch, 1703); Houtteville, Religion chrétienne, 1:182; Rudolphe du Tertre, Entretiens sur la religion, où l'on établit les fondements de la religion révélée contre les athées et les deists, 3 vols. (Paris: Clousier, David, Durand, and Damonneville, 1743); cf. [Charles-François Alexandre], l'abbé d'Houtteville, La religion chrétienne prouvée par les faits, 4 vols. (Amsterdam: Henri du Sauzet, 1744); L'abbé Rudolphe du Tertre, Entretiens sur la religion, où l'on établit les fondemens de réligion révélée contre les athées et les déistes, 3 vols. (Paris: Clousier, David, Durand, and Damonneville, 1743).

41 Thierry Meynard, S.J., The Jesuit Reading of Confucius: The First Complete Translation of the Lunyu (1687) Published in the West (Leiden: Brill, 2015); David Mungello, Great Encounter of China and the West, 1500-180o (Lanham, MD: Rowman \& Littlefield, 1999), 84-85; and Henri Pinot, La Chine et la formation de l'ésprit philosophique en France, 1640-1740 (Geneva: Slatkine Reprints, 1971), 367-76; Donald F. Lach and Edwin J. Van Kley, Asia in the Making 
The Jesuit translation of Chinese cultural history into the public sphere of the seventeenth and early eighteenth centuries - much like their translation of Indian, Southeast Asian, and Amerindian culture into the mental world of early modern culture - ultimately ignited a contentious debate between those positing that the original, natural, monotheistic religion of humanity had degenerated into idolatry, thus necessitating revealed religion in general (and that of the Catholic Church in particular), and those who argued that polytheism was in fact the ubiquitous characteristic of original natural religion. ${ }^{42}$ As is well known, the works of Chinese philosophy, history, and linguistics produced or translated by Jesuits became the principal source base for European knowledge of China, and thus a wide range of Enlightenment authors, from Voltaire (1694-1778) to Herder (1744-1803), to the anti-philosophe apologetics of Nicolas-Sylvestre Bergier (1718-90), utilized them to disparate and diverse ends. ${ }^{43}$ Important to stress in connection to the distinctiveness of Jesuit contributions to the eighteenth century is the observation that both sides in the debate over the nature of the original religion of humanity referred back to Jesuit texts and debates. Even the nearly eighty pages of text and fourteen engravings contained in volume 4 of Cérémonies et coutumes religieuses de tous les peuples du monde (Religious ceremonies and customs of all of peoples

of Europe, 3 vols. (Chicago: University of Chicago Press, 1993), 3:1752-53; also David Porter, "China and the Critique of Religious Fanaticism in Eighteenth-Century France," in Les Lumières européens dans leurs relations avec les autres grandes cultures et religions, ed. Florence Lotterie and Darrin M. McMahon (Paris: Honoré Champion, 2002), 61-80; David Porter, Ideographia: The Chinese Cipher in Early Modern Europe (Stanford, CA: Stanford University Press, 2001), 8.

Stroumsa, New Science, 77-100, 145-9; in addition to Philippe Couplet, Louis Le Comte's $\left(1655^{-1728}\right)$ French translation circulated widely throughout Europe, and was itself translated and abridged many times; other influential Jesuit texts included Jean-Baptiste du Halde, Description géographique, historique, chronologique, politique, et physique de l'empire de la Chine et de la Tartarie chinoise [...] (La Haye: H. Scheurleer, 1736); [Charles le Gobien], Lettres édifiantes et curieuses de Chine par des missionnaires jésuites, 1702-1776, ed. Isabelle and Jean-Louis Vissière (Paris: Garnier-Flammarion, 1979); for a more complete and systematic account of the Jesuit output in China, see Lach and Van Kley, Asia in the Making of Europe, 3:1676-87, 1731-48.

43 François-Marie Arouêt de Voltaire, Essai sur les moeurs et l'esprit des nations et sur les principaux faits de l'histoire depuis Charlemagne justqu'à Louis XIII, 3 vols., in Oeuvres complètes de Voltaire, ed. T. Beuchot, new ed. (Paris: Garnier, 1878), 11:176-77; Johann Gottfried von Herder, Outlines of a Philosophy of the History of Man, trans. T. Churchill (London: Bergman, 1966; Leipzig and Riga: Johann Friedrich Hartoch, 1784), 292; Clorinda Donato, "Le Nouveau Monde et l'apologie du catholicisme dans le Dictionnaire de théologie (17891790) de l'abbé Bergier," Tangence 72 (Summer 2003): 57-73. 
of the world, 1723-43), published by Bernard Picart (1673-1733) and Jean Frédéric Bernard (1683-1744), two leading Huguenot diaspora publishers, was, at least structurally, a compendium of Jesuit texts concerning China. ${ }^{44}$

Bernard and Picart were part of the Chevaliers de la jubilation (Knights of jubilation), a Masonic society at the heart of Jacob's research, and no less, at the heart of a network of avant-garde Francophone publishers and writers in The Hague who promoted rational religious reform and religious toleration. The circle included Marc-Michel Rey (1720-80), Picart's son-in-law and one of the most prosperous of later Enlightenment publishers. This group of publishers and scholars was also close to those who would publish the Traité des trois imposteurs (Treatise of the three imposters, 1719, 1721) designed to problematize the credibility of Jesus, Moses, and Muhammad altogether. But less well known is the fact that both Bernard and Picart were interested in Jesuit missionary texts concerning China, most likely through their fellow Chevalier de jubilation, Prosper Marchand (1678-1756), who had once been a regular collaborator with the Sinophile Jesuit, Tournemine, on the Mémoires de Trévoux scarcely a decade before Marchand's conversion to Protestantism and resulting flight into the Low Countries. ${ }^{45}$ Bernard and Picart thus reproduced an abridgment of the debates over the nature of Chinese religion based largely in Jesuit writings, but their compendium left the heart of the matter dangling without resolution. ${ }^{46}$ The answer implied by Cérémonies et coutumes religieuses de tous les peuples du monde seemed to be, in the words of Wijnand Mijnhardt, that "religious customs and ceremonies had kept the people in Europe, Asia, Africa, and the Americas from seeing the universal truths for

44 Wijnand Mijnhardt, "Jean Frédéric Bernard as Author and Publisher," in Bernard Picart and the First Global Vision of Religion, ed. Lynn Hunt, Margaret Jacob, and Wijnand Mijnhardt (Los Angeles: Getty Research Institute Publications, 2010), 17-34.

45 Ibid., 23-27; on the Tournemine-Marchand connection, see Christiane BerkvensStevelinck, Prosper Marchand: La vie et l'oeuvre (1678-1756) (Leiden: Brill, 1987), 109-10; Jacob, Living the Enlightenment; Margaret C. Jacob, Strangers Nowhere in the World: The Rise of Cosmopolitanism in Early Modern Europe (Philadelphia: University of Pennsylvania Press, 2006).

46 According to historian Marcia Reed, the footnotes reference the Jesuit Martino Martini's (1614-61) Histoire de la Chine, and Confucius Sinarum philosophus, Le Comte's Nouveaux memoires sur l'etat present de la Chine?, German Jesuit Athanasius Kircher's (1602-80) Chine illustrée, and Lettres édifiantes et curieuses (reports from various Jesuit foreign missions): see Marcia Reed, "Bernard Picart on China: 'Curious' Discourses and Images Taken Principally from Jesuit Sources"; and Catherine E. Clark, "Chinese Idols, Religious Art: Questioning Difference in Cérémonies et coutumes religieuses," in Hunt, Jacob, and Mijnhardt Bernard Picart and the First Global Vision of Religion, 216; 235-51. 
natural religion."47 Jesuit texts and philosophical debates thus became, ironically, the stimuli for the further radicalization of the Enlightenment, despite the avowedly Catholic and apologetical mission of the Jesuits themselves.

Though the use to which freethinking Enlightenment authors often put Jesuit works was for the most part quite at variance from the original purpose of the Jesuit missionary-scholars themselves, it is important to note that by the eighteenth century, controversies over whether the prisca theologia (pristine theology) was theistic or materialistic divided even Jesuits against themselves. As Marie-Hélène Cotoni has argued, religious writers engaged in many of the same debates as more radical or secular writers. Citations and outright borrowing from all of these diverse sources find themselves entangled within the same clandestine writings that circulated in academies, masonic lodges, lending libraries, salons, and political clubs throughout the eighteenth century. ${ }^{48}$ Indeed, the historical research of some Jesuits themselves reached troubling conclusions that could be taken by readers to imply that a kind of materialist atheism may have been just as common as theism in distant antiquity. Nicolò Longobardi (1559-1654), Ricci's successor as leader of the Chinese mission, had already complicated Ricci's original assumption that the Chinese, like all other peoples on earth, were originally monotheistic. Longobardi had discovered that the most ancient Chinese classics possessed no clear idea of immaterial deity, a finding which necessarily implied that the natural religion of humanity might just as easily have been rooted in materialism or atheism. In effect, Longobardi's position is not far from the one espoused by the young Marquis d'Argens (1704-71), who believed that primitive Confucianism had affinities with Spinoza or other materialists. ${ }^{49}$ Even Jesuit classical philology closer to

47 Mijnhardt, "Jean Frédéric Bernard as Author and Publisher," 18.

48 Marie-Hélène Cotoni, L'exégèse du Nouveau Testament dans la philosophie française du dix-huitième siècle (Oxford: Voltaire Foundation, 1984), 124-26, 196; Olivier Bloch, ed., La matérialisme du XVIIIe siècle et la littérature clandestine: Actes de la table ronde des 6-7 juin 1980 (Paris: Librairie Philosophique J. Vrin, 1982).

49 Jean Baptiste Boyer, le marquis d'Argens, Lettres chinoises ou correspondence philosophique, historique et critique entre un chinois voyageur \& ses correspondans à la Chine, en Moscovie \& au Japon, 6 vols., nouvelle edition augmentée de nouvelles lettres \& de quantité de remarques (La Haye: Pierre Paupie, 1769), 1:138-39; Basil Guy, The French Image of China before and after Voltaire (Geneva: Institut et Musée Voltaire les Délices, 1963), 116-20; Israel, Enlightenment Contested, 640-62; David Porter, "China and the Critique of Religious Fanaticism in Eighteenth-Century France," in Lotterie and McMahon, Les Lumières européens dans leurs relations avec les autres grandes cultures et religions, 61-80; see also Jonathan I. Israel, "Admiration of China and Classical Chinese Thought in the Radical Enlightenment (1685-1740)," Journal of East Asian Studies 4, no. 1 (issue 7) (June 2007): $1-25$. 
home in Europe proved an unlikely source of Enlightenment religious controversy. Father Alexandre Pierre-Joseph Thoulier d'Olivet (1682-1768), a regular correspondent with Voltaire even after the two began to disagree over the potentially materialist implications of Newton (1643-1727) and Locke, completed a new critical translation of De natura deorum (On the nature of the gods) by Cicero (107-44 ВСE). ${ }^{50}$ De natura deorum was highly recommended by Jesuits such as d'Olivet's colleague, Tournemine, for use in Jesuit colleges and schools, yet the critical remarks of d'Olivet's translation implied that the vast majority of Greek philosophers had actually possessed materialist conceptions of the cosmos, and were therefore (as most Catholics then understood it) atheistic. ${ }^{51}$ As Kors has noted, this tendency to find atheists lurking behind every tree and under seemingly every rock-among the sages of ancient Greece and Rome as well as those of China—not only globalized the European understanding of the history of religion but may have accomplished as much as Bayle's notion that a morally upright society of atheists was possible in undermining the Catholic doctrine of universal consent that Jesuits, themselves, cherished. ${ }^{52}$ Though it cannot be said that Jesuits intended this outcome, it seems hard to dispute that important individual examples of seventeenth- and eighteenth-century Jesuit erudition ironically contributed to the undermining of one of medieval and early modern Catholicism's most cherished notions - that all peoples originally possessed the same natural theology that declared the glory of one, anthropomorphic, immaterial deity. ${ }^{53}$ Kors may be prescient on this score given that Mémoires de Trévoux scarcely criticized d'Olivet's translation, and it later circulated in French translation after 1721. Indeed, De natura deorum was constantly cited throughout the eighteenth century by popular radical authors including Benoît de Maîllet (16561738) in Telliamed which argues for the plurality of other worlds beyond earth,

5o Father Thoulier was the prefect of Voltaire's residence while the latter was a student at Louis-le-Grand from 1704 to 1711; René Pomeau, "Voltaire au Collège," Revue d'histoire littéraire de la France $5^{2}$ (1952): 1-10; Voltaire's acquaintance with Tournemine during the latter's tenure as librarian of the maison profess associated with Louis-le-Grand dates to the same time: John Pappas, "L'influence de René-Joseph Tournemine sur Voltaire," Annales de Bretagne et des pays de l'ouest (Anjou, Maine, Touraine) 83, no. 4 (1976): 727-35; also René Pomeau, La religion de Voltaire (Paris: Nizet, 1969), 42.

$5^{1}$ Kors, Atheism in France, 1:210-17; [Tournemine], "Instructions des Regens par le Père Tournemine," "Mélanges sur les jésuites, xvııı siècle": BnF, Nouvelles acquisitions françaises $10946,318$.

Perez Zagorin, How the Idea of Religious Toleration Came to the West (Princeton, NJ: Princeton University Press, 2003), 271-72. 
the possibility that earlier species of humans may have once populated earth, and that the climate and geology of the earth are self-evolving. ${ }^{54}$

In light of the frequency with which eighteenth-century writers uncovered examples of materialism in the traditions of ancient non-European societies like China as much as in the more familiar antiquities of the Greeks and Romans, some scriptores felt themselves impelled to devise creative ways of adapting their apologetics accordingly. In a series of reflections on atheism posthumously published in a 1776 revised edition of François Fenelon's (16511751) philosophical works, Tournemine went so far as to argue that "there are no true atheists," not even among followers of Spinoza. All atheism is merely the willful attachment to metaphysical confusions that obscure the natural sentiment of humanity that God must exist. ${ }^{55}$ Even the Chinese scholar gentry—whom Bayle (1647-1706), Malebranche (1638-1715), d'Argens (1704-71), and the Jesuit Longobardi himself considered to be atheistic-Tournemine reframed as closet theists who possessed erroneous ideas about divinity and nothing more. ${ }^{56}$ He continued with grace and beauty to describe the pious metaphysics of the Chinese literati, some of whom were undoubtedly known to Tournemine's pupils and colleagues in the mission field: "One could not speak of the Divinity in terms more magnificent than those employed by the literati of China [...]. They express themselves as we do on the creation, the

54 Ibid., 210-11, 217; [Gerard de Maillet], Telliamed, 2 vols. (Amsterdam: L'Honoré, 1748), 1:iv-v, xvii-xxi, xxv-xxxiv; for more on Maillet and the Telliamed, see Miguel Benítez, La face cachée des Lumières: Recherches sur les manuscrits philosophiques clandestins de l'âge classique (Paris: Voltaire Foundation, 1996); Le Mascrier, an ex-Jesuit, republished both the Telliamed and Bernard Picart's Cérémonies et coutumes religieuses des tous les peuples du monde (originally published between 1723 and 1743): see Lynn Hunt and Margaret Jacob, "Introduction" and Mijnhardt, "Jean Frédéric Bernard as Author and Publisher," in Hunt, Jacob, and Mijnhardt, Bernard Picart and the First Global Vision of Religion, 1-13; 117-34; Lynn Hunt, Margaret Jacob, and Wijnand Mijnhardt, Decoding the Divine: The Religious Ceremonies and Customs of All the Peoples of the World (Cambridge, MA: Harvard University Press, 2010).

55 "Réflexions du Père Tournemine, Jésuite, sur l'athéisme, sur la demonstration de Monseigneur de Cambray, et sur le systême de Spinosa qui ont servi de préface aux deux editions precedents de la Démonstration," in François de Salignac de la Motte Fenelon, Oeuvres philosophiques, nouvelle édition augmentée des Réflexions du Pere Tournemine (Paris: Pierre Delaire, 1776), 377-412.

56 Nicolas Malebranche, Entretiens d'un philosophe chrétien et d'un philosophe chinois sur l'existence et la nature de Dieu, in Thèse complémentaire pour le doctorat ès lettres, presentées par Augustin Le Moine, Université d'Aix-Marseilles, faculté des Lettres d'Aix (Marseilles: Imprimerie et Lithographie, 1936), 47-92; D'Argens, Lettres chinoises, 1:138-48; "Réflexions du Père Tournemine," in Fenelon, Oeuvres philosophiques, 381-82. 
conservation of the universe, and providence." ${ }^{57}$ Whatever essence God is assumed by "idolaters" to possess, if a people or philosopher continues to ascribe intelligence and agency to it/her/him, then clearly they cannot be called atheists. Atheism, in Tournemine's estimation, is nothing more than skepticism masquerading as bad philosophy with a dash of hubris. In fact, Tournemine's argument actually borrows its thesis— that "surely to forget God is not atheism"58 - from Bayle, with whom he regularly grappled and, in limited ways, admired. ${ }^{59}$ Bayle's work had underscored the observation that some knowledge of God, however obscure, remains a precondition of idolatry (which he had defined as corrupted theism). ${ }^{60}$

The Jesuit notion that efficacious grace had been withdrawn at the fall thus leaving the human soul gradually unable to discern and practice the primitive revelation of God once natural sentiments and perceptions were warped by fear and passions, had led some Jesuits to very distinctive conclusions. For if Spinozan or modern Confucian atheism were really just species of modern idolatry presupposing the complexity and refinement of civilizations in Europe or China, then might not the moral and religious values of supposedly primitive peoples be much closer to that unsullied natural theology practiced by all humankind in its infancy? Certainly, some Jesuits flirted with this possibility throughout the eighteenth century, a fact exemplified by the former director of the Chinese missions, and one-time editor of Lettres édifiantes et curieuses, Charles Le Gobien (1653-1708).

Le Gobien recounts an address given by a leader of the failed 1685 revolt against the Spanish by the indigenous peoples of Guam. No doubt Le Gobien shapes the narrative according to the narrative conventions of the classical harangue, but how much more then is this evidence of the globalization of Jesuit horizons and their ability to provincialize their own European milieu? Le Gobien's report of the Guam freedom fighter reads as follows:

We had what our Islands gave us; we relied on that, we did not want anything else. The knowledge they gave us made our needs bigger, our desires

57 "Réflexions du Père Tournemine," in Fenelon, Oeuvres philosophiques, 381-82, also 393-94.

$5^{8}$ Ibid., 380 .

59 Matytsin notes Tournemine's relatively "warm appraisal" of Bayle, but this does contrast with some of his more assertive critics among the French Jesuits, such as, for example, that of Jacques Le Febvre in Bayle en petit (1737): Matytsin, "Specter of Skepticism," 5-55, 119. 
sharper. [...] They think we are simpletons; they look on us as Barbarians. But should we believe them? Is it not clear enough that, by pretending to teach us and polish our customs, they are corrupting us? That they spoil that first simplicity in which we used to live? That they take away our freedom that we should cherish more than life? [...] They regard our histories as fables and fictions. Are we not entitled to say the same about what they teach us, asking us to believe it as incontestable truth? ${ }^{61}$

Le Gobien's text (which elsewhere cites Montaigne's Essays and went on to inspire Diderot's Supplément au voyage de Bougainville) rhetorically dramatized the possibility that, in reclaiming societies for Christ, a relative age of primitive socio-political innocence may also have been lost, and values such as civilization and barbarism are perhaps relative. ${ }^{62}$ If, as this chapter has shown, Jesuit contributions to the eighteenth century exist in recursive and mutually constructive dialogue with the more mainstream Enlightenment, while remaining largely separate from the Enlightenment as such, then it must also be said that at least a minority of Jesuits were occasionally willing and able to express views largely identical to more radical thinking concerning the nature of the soul, atheism, the history of religion, and the virtues of primitive societies.

\section{Conclusion}

The greatest paradox of Jesuit distinctiveness during the century of the Enlightenment is the fact that they were so often victims of their own prowess as philosophers and sacred historians. In the tremendously popular Nouvelles ecclésiastiques, a story circulated about how Father Tournemine had delivered a sermon at Caen in 1730 in which he was rumored to have exclaimed that the only way to attain rational certainty concerning St. Matthew's authorship of the canonical Gospel that bears his name would be to verify the original Hebrew orthography (a historical impossibility). His point seems to have been that the authority vested in these gospels by Rome was their main source and

61 Charles Le Gobien, Histoire des Isles Marianes, nouvellement converties à la religion chrestienne; et de la mort glorieuse des premiers missionnaires quiy ont prêché la foy (Paris, 1700); quoted in Carlo Ginzburg, "Alien Voices: The Dialogic Element in Early Modern Jesuit Historiography," in History, Rhetoric, and Proof, ed. Carlo Ginzburg (Hanover, NH: University Press of New England, 1999), 72-73.

62 Ginzburg, “Alien Voices," 73, 79. 
seal of divine inspiration. Father Hardouin also got carried away with textual criticism in his anti-Protestant apologetics, arguing that many texts of the church fathers of late antiquity had been altered or outright forged in the thirteenth century. ${ }^{63}$ Within the context of eighteenth-century Jesuit apologetics, both Tournemine and Hardouin were merely attempting to remind readers that the authenticity of scriptures had been vouchsafed by eye-witnesses who then wrote the early texts of the church, which in turn, had been vouchsafed and interpreted by that church as a living monument bereft of sound refutation throughout the centuries in a way that guaranteed an unbroken chain of historical transmission. Taken in another way, however (as increasingly it was by free thinkers, skeptics, and for other reasons, anti-Jesuit polemicists among the Jansenists), the rhetorical skepticism that had served the apologetical pursuits of the Jesuits so well also suggested that they were conceding far too much to skeptics and heretics by appealing directly to the authority of the church for whatever could not be affirmed by individual critical reason and scholarly investigations. If the eighteenth-century Enlightenment is an intellectual revolution of sorts, and if revolutionaries often cannibalize their own forebears, then I would like to suggest that the rise of anti-Jesuit criticism culminating in the suppression of the order was at least in some measure the vengeance of more radical writers of the eighteenth century on their own former teachers despite the best apologetically inclined intentions of the latter. ${ }^{64}$

63 John McManners, Church and Society in Eighteenth-Century France (Oxford: Clarendon Press, 1998), 2:542; it must be noted that Jean Hardouin was far too radical for many of his fellow Jesuits, and was himself heavily criticized by them; even Tournemine was his bitter polemical foe: see Michel Pierre Joseph Picot, Mémoires pour servir à l'histoire ecclésiastique pendant le dix-huitième siècle, 3rd ed. (Paris: Librairie d'Adrien Le Clerc, 1853), 2:452-54.

64 For the relationship of the Jesuit suppressions with Jansenist and Gallican critic, and the rise of anti-Jesuitism in Europe more generally, see Dale K. Van Kley, The Jansenists and the Expulsion of the Jesuits from France (New Haven: Yale University Press, 1975); Van Kley, "Jansenism and the International Expulsion of the Jesuits," in Cambridge History of Christianity, vol. 7: Reawakening Revolution, 1660-1815, ed. Stewart J. Brown and Timothy Tackett (Cambridge: Cambridge University Press, 2006), 302-28. 